\title{
Az alkotmány alapvető struktúrájának bírói védelme: az alkotmánymódosítások bírói felülvizsgálatának gyakorlata Indiában
}

\author{
India - alkotmányellenes alkotmánymódositás - az alkotmány alapvető \\ struktúrája - bírói felülvizsgálat
}

\begin{abstract}
A fennálló alkotmány bírói védelmének egyik ritkán előforduló, ám nagy jelentőségü esete az alkotmánymódosítások felülvizsgálata. Az alkotmánymódosítások bírói felülvizsgálata a közelmúltig partikulárisnak tűnt, de az elmúlt években a nemzetkö$z^{1}{ }^{1}$ és a hazai ${ }^{2}$ jogtudományi diskurzus fókuszába került. Jóllehet az alkotmányelle-
\end{abstract}

* Dr. Zsugyó Virág doktorjelölt, Debreceni Egyetem Marton Géza Állam- és Jogtudományi Doktori Iskola, virag.zsugyo@gmail.com.

1 Lásd például AlBeRT, Richard: Amending Amendment Rules. International Journal of Constitutional Law, 2015/3, 655-685; BARAK, Aharon: Unconstitutional constitutonal amendments. Israel Law Review, 2011/3, 321-341; BernaL, Carlos: Unconstitutional constitutional amendments in the case study of Colombia: An analysis of the justification and meaning of the constitutional replacement doctrine. International Journal of Constitutional Law, 2013/2, 339-357; DIXoN, Rosalinde-LANDAU, David: Transnational Constitutionalism and a Limited Doctrine of Unconstitutional Constitutional Amendment. International Journal of Constitutional Law, 2015/3, 606-638; Gözler, Kemal: Judicial Review of Constitutional Amendments: A Comparative Study. Ekin Press, Bursa, 2008; JACOBSOHN, Gary Jeffrey: An unconstitutional constitution? A comparative perspective. International Journal of Constitutional Law, 2006/3, 460-487; Kumm, Mattias: Constituent power, cosmopolitan constitutionalism, and post-positivist law. International Journal of Constitutional Law, 2016/3, 697-711; Roznal, Yaniv: Unconstitutional Constitutional Amendments. The Limits of Amendment Powers. Oxford University Press, Oxford, 2017.

2 Lásd például Bragrova András-Gárdos-Orosz Fruzsina: Vannak-e megváltoztathatatlan normák az Alaptörvényben? Állam- és Jogtudomány, 2016/3, 35-63; Chronowskı Nóra-Drinóczı Tímea-ZelLeR Judit: Túl az alkotmányon... Közjogi Szemle, 2010/4, 1-12; Drinóczı Tímea: Újra az alkotmányozó, az alkotmánymódosító hatalomról és az alkotmányellenes alkotmánymódosításról - az Alaptörvény alapján. Jogtudományi Közlöny, 2015/7-8, 361-378; FRöHLICH Johanna: Az alkotmány zártsága és ellentmondás-mentessége - az alkotmánymódosítások felülvizsgálatának lehetőségei és határai. In: Szente Zoltán-Gárdos-Orosz Fruzsina (szerk.): Alkotmányozás és alkotmányjogi változások Európában és Magyarországon. NKE KIK, Budapest, 2014, 196-208; GÁrdos-Orosz Fruzsina: Az alkotmánymódosítások alkotmányossági felülvizsgálata: elméleti koncepciók, nemzetközi trendek és magyar kérdések. In: Szente Zoltán-Gárdos-Orosz Fruzsina (szerk.): Alkotmányozás és alkotmányjogi változások Európában és Magyarországon. NKE KIK, Budapest, 2014, 167-184; Halmal Gábor: Alkotmányos alkotmánysértés. Fundamentum, 2011/2, 81-98; PetrÉtEI József: Az alkotmányozó hatalom és az alkotmányosság. In: Szente Zoltán-Gárdos-Orosz Fruzsina (szerk.): Alkotmányozás és alkotmányjogi változások Európában és Magyarországon. NKE KIK, Budapest, 2014, 49-67; SZENTE Zoltán: Az „alkotmányellenes alkotmánymódosítás” és az alkotmánymódosítások bírói felülvizsgálatának dogmatikai problémái a magyar alkotmányjogban. In: Szente Zoltán-Gárdos-Orosz Fruzsina (szerk.): Alkotmányozás és alkotmányjogi változások Európában és Magyarországon. NKE KIK, Budapest, 2014, 209-241. 
nes alkotmánymódosítások problémája számos elméleti kérdést vet fel, és a probléma komplexitása, valamint gazdag elméleti háttere miatt a bíróságoknak kihívást jelent erről dönteni, mégis az alkotmánymódosítások bírói felülvizsgálatának mára kiterjedt gyakorlata van. A módosítások felülvizsgálatát elvégző bíróságok közül az indiai legfelső bíróság gyakorlata mintaadónak számít.

India alaptörvénye nem tartalmaz sem megváltoztathatatlan rendelkezést, sem explicit felhatalmazást az alkotmánymódosítások bírói kontrolljára. Az indiai legfelső bíróság (a továbbiakban: Bíróság) már nagyon korán, az önálló, független India létrejötte után néhány évvel, 1951-ben találkozott az alkotmányellenes alkotmánymódosítás kérdésével. Az 1950-es években és az 1960-as évek elején csak formai szempontból vizsgálta felül a módosításokat, azonban Indira Gandhi miniszterelnök vezetésével a parlament többsége 1966-tól egyre gyakrabban módosította az alkotmányt azért, hogy Gandhi politikai akaratát véghez vigye. Ebben a környezetben alakította ki a Bíróság az indiai alkotmány alapvető struktúráját védő doktrínáját, ami például szolgált és szolgálhat nemcsak azon államok bíróságai számára, amelyek alkotmányának nincs megváltoztathatatlan rendelkezése és a bíróságnak nincs kifejezett felhatalmazása az alkotmánymódosítások felülvizsgálatára, hanem minden más demokratikus állam bíróságai számára is. A Bíróság gyakorlata értékes hozzájárulás az alkotmányozó és alkotmánymódosító hatalom megítéléséhez, az alkotmányos demokrácia értékeinek védelméhez, az alkotmánymódosítás implicit korlátainak azonosításához és az autokratikus törekvések felismeréséhez.

\section{Az alkotmánymódosítás implicit korlátai}

A Bíróság gyakorlata tipikus példája annak, amikor egy bírói testület implicit korlátot állít az alkotmánymódosításokkal szemben. Az alapvető struktúra doktrína elemzése előtt ezért érdemes röviden áttekinteni az implicit korlátok természetét és igazolhatóságának néhány felmerülő kérdését.

Implicit korlátokról beszélhetünk, ha az alkotmány módosításának korlátai az alkotmány elvei, értékei, céljai alapján bírói értelmezéssel határozhatók meg. Megkülönböztethetünk azonban szövegszerüen az alkotmányban meghatározott kifejezett, azaz explicit korlátokat is. Az alkotmánymódosítások bírói felülvizsgálata szempontjából lényeges tényező, hogy tartalmaz-e az adott alkotmány kifejezett korlátot az alkotmánymódosításokra vagy sem. Ha azonosítható ilyen rendelkezés, akkor a bíróságok jellemzően gyakrabban vállalják fel a módosítások alkotmányossági vizsgálatát, mivel könnyebben meghatározható a mérce, amihez képest dönthetnek az alkotmánymódosítások elfogadhatóságáról. Például Németország, Csehország vagy Brazília alkotmánya megváltoztathatatlan rendelkezéseket tartalmaz, és ezekben az államokban a bíróságok el is végzik az alkotmánymódosítások felülvizsgálatát.

A kifejezett érdemi korlátok érvényessége vitán felül áll, mert az alkotmányba az alkotmányozó hatalom fektette le. Ezért az alkotmány által létrehozott és szabályozott alkotmánymódosító hatalom számára az alkotmány korlátot jelent. ${ }^{3} \mathrm{~A}$ kife-

3 GözleR: i. m., 52. 
jezett korlátok gyakorlatilag a megváltoztathatatlan rendelkezésekkel azonosíthatók. A megváltoztathatatlan rendelkezések alkalmazása általában egyszerre fejez ki bizalmatlanságot a jövőbeni alkotmánymódosító hatalmat gyakorlókkal szemben, és mutatja a megváltoztathatatlannak ítélt rendelkezés fontosságát, értékét az adott közösség számára. ${ }^{4}$

Yaniv Roznai a világon 1789 és 2015 között létező 742 alkotmányt megvizsgálva arra jutott, hogy egyre gyakoribb a megváltoztathatatlan rendelkezések alkalmazása. Míg az alkotmányosság első hullámában, 1789 és 1944 között csupán az ebben az időszakban elfogadott alkotmányok 17\%-a tartalmazott megváltoztathatatlan rendelkezést, addig ez az arány 1945 és 1988 között 27\%-ra emelkedett, míg 2015-re majdnem megduplázódott. 1989 és 2015 között az alkotmányok 54\%-a tartalmazott megváltoztathatatlan rendelkezést. A megváltoztathatatlan rendelkezések gyakorisága mellett hosszuk és összetettségük, részletezettségük is megnőtt a vizsgált időszakban. Ez azzal magyarázható, hogy a második világháború előtt a megváltoztathatatlan rendelkezések föként az államformát védték, míg azóta, az alkotmányosodás új hullámával már az alapvető jogokra és a demokrácia lényeges elemeire is kiterjednek. ${ }^{5}$

Az implicit korlátok a kifejezett korlátokkal szemben nem azonosíthatók olyan egyértelműen. Az alkotmány elvei, értékei, céljai alapján bírói értelmezéssel határozhatók meg. Mégis számos - például dél-ázsiai és latin-amerikai - bíróság állított implicit tartalmi korlátokat a formális alkotmánymódosítások elé, és érvénytelenítette azokat. Ennek ellenére az implicit korlátok érvényessége nem magától értetődő. Vannak olyan vélemények, amelyek szerint implicit korlátok nincsenek, vagy a bíróság nem azonosíthatja azokat. Ugyan a bíróságok a gyakorlatban érvénytelenítik az alkotmányellenesnek ítélt alkotmánymódosításokat, de normatív szinten kérdés, hogy kell-e a bíróságoknak érvényteleníteni a módosításokat akkor, ha az alkotmány nem rendelkezik kifejezetten az alkotmánymódosítás tartalmi korlátairól. A bíróságok állapíthatnak-e meg implicit korlátokat? ${ }^{6}$ Po Jen Yap szerint az implicit korlátok alkalmazását támogatóknak választ kellene adniuk arra a kérdésre, hogy miért elörébb való minden esetben a bíróság felfogása az emberi méltóságról, mint a módosító hatalom felfogása, ${ }^{7}$ hiszen az alapvető normákat lehetetlen objektíven és értéksemlegesen meghatározni, ha az alkotmány maga nem tesz különbséget egyes rendelkezései között. ${ }^{8}$

Ha az alkotmányosság talaján állva elfogadjuk az alkotmány felsőbbségét és a korlátozott hatalom eszméjét, akkor arra jutunk, hogy az implicit korlátokat - mint az indiai alapvető struktúra és az ahhoz hasonló doktrínák - nem a bírák preferenciái alakítják, hanem a korlátozott hatalom kontextusában az alkotmányozó hatalom ter-

Roznal (2017): i. m., 17.

Roznal (2017): i. m., 20-21.

6 YAP, Po Jen: The conundrum of unconstitutional constitutional amendments. Global Constitutionalism, 2015/4, 123.

7 YAP: i. m., 123.

8 TRIBE, Laurence H.: A Constitution We Are Amending: In Defence of a Restrained Judicial Role. Harvard Law Review, 1983/2, 433. Idézi YAP: i. m., 123. 
mészetéből következnek. ${ }^{9} \mathrm{Az}$ alkotmánymódosítás ugyanis kifejezett rendelkezések hiányában is korlátozott, és csak olyan lehet, ami az alkotmány egészének önazonosságát és folytonosságát megőrzi, nem rombolja le annak rendelkezéseit. ${ }^{10}$

Mivel az alkotmány sem értéksemleges, ezért valóban nem lehet értéksemlegesen meghatározni az alkotmánymódosítások implicit korlátait. A korlátok az alkotmány tartalmi rendelkezéseiből kiolvashatók, mégis nehézséget okozhat ezek azonosítása. ${ }^{11} \mathrm{~A}$ bíróság számára több támpont is segíthet, mint például korábban kialakított gyakorlata és az állam által vállalt nemzetközi kötelezettségek. Bár nem minden esetben egyszerü meghatározni, hogy mi tartozhat az alkotmány alapvető struktúráját adó implicit korlátok közé, nyilvánvaló esetek is előfordulnak, amikor a bíróság könnyen megállapíthatja egy alkotmánymódosítás alkotmányellenességét: például ha olyan rendelkezést akarnak alkotmánymódosítással beiktatni, amelyet korábban alkotmányellenesnek ítélt a testület. Ilyen esetekben, ha elfogadjuk a felülvizsgálatot, akkor többet nyerünk, mint ha elutasítjuk azon az alapon, hogy nagyon nehéz meghatározni, mi alapvető elem az alkotmányban, és ezzel a bíróság akár vissza is élhet. A bíróság ugyanis felépítéséből és működési elveiből adódóan sokkal kevésbé hajlamos önkényes döntéseket hozni, mint a közvetlenül a választók támogatásától függő képviselök. Ráadásul ez az ellenérv általánosságban is felvethető, mert az alkotmányos elvek, jogok absztrakt megfogalmazásuk miatt akkor is többféle értelmezést tesznek lehetővé, ha jogszabályok alkotmányosságáról dönt a bíróság. Tehát ha a jogszabályok bírói felülvizsgálatának szükségességét elfogadjuk, akkor ez az ellenérv nem elég ahhoz, hogy elvessük az alkotmánymódosítások bírói felülvizsgálatát.

George Wright szerint az amerikai alkotmány V. cikke ugyan nem határoz meg tartalmi korlátot az alkotmánymódosító hatalom felé (a szerző a tagállamok szavazati jogának sérthetetlenségét eljárásinak tekinti), de az amerikai és talán minden alkotmány ellenőrizhető előfeltételezéseiből és céljaiból következnek az alkotmánymódosítás nem kifejezett érdemi korlátai. Ez logikusan következik egyrészt abból a feltevésböl, hogy az alkotmánynak vannak céljai, másrészt abból a követelményböl, hogy az alkotmány minimálisan egységes, koherens dokumentum. ${ }^{12} \mathrm{Az}$ alkotmányozás egy szándékolt, célvezérelt cselekvés, és ezek a célok maguk is a morális értékekről, az emberről és a világ müködéséről alkotott előfeltevéseken nyugszanak. Az elöfeltevések között vannak, amelyek pontosan beazonosíthatók, és vannak, amelyek kevésbé egyértelmüek. ${ }^{13}$ Lehet úgy érvelni, hogy az alkotmánynak nincs meghatározott lényege vagy szelleme, és így nincs egyetlen rendelkezés vagy cél sem, amelyet ha kicserélünk, az szükségszerüen lerombolja az alkotmány identitá-

9 Keshavamuthy, C. V.: Amending Power Under the Indian Constitution: Basic Structure Limitations. Deep \& Deep, New Delhi, 1982, 89. Idézi RoznAl, Yaniv: Unconstitutitonal Constitutional Amendements - The Migration and Success of a Constitutional Idea. The American Journal of Comparative Law, 2013/3, 717.

10 Schmitт, Carl: Constitutional Theory. Duke University Press, Durham, London, 2008, 150-153.

11 SAMAR, Vincent: Can a constitutional amendment be unconstitutional? Oklahoma City Law Review, 2009/3, 677-678.

12 WRIGHT, R. George: Could a Constitutional Amendment Be Unconstitutional? Loyola University Chicago Law Journal, 1991/4, 742-743.

13 WRIGHT: i. m., 745. 
sának folytonosságát. Ez azonban inkább annak az eredménye, hogy a nem kifejezett érdemi korlátok valódi tartalma nem azonosítható az alkotmány meghatározott rendelkezéseivel, amelyekkel ellentétes alkotmánymódosítást biztosan alkotmányellenesnek lehet tekinteni. Megfordítva, nem mondhatjuk, hogy nem alkotmányellenes az a módosítás, amely nem áll ellentétben a néhány kiválasztott alkotmányos rendelkezéssel. ${ }^{14}$

\section{A Bíróság gyakorlatának keretei}

India ma is hatályban lévő alkotmányát 1949. november 26-án fogadták el, és 1950. január 25-én lépett hatályba. Ezzel a japán mellett Ázsia legrégebbi alkotmányai közé tartozik. Az alkotmány sikerességét alkalmazkodási képességének tulajdonítja Mahendra Pal Singh, aki szerint az ország mérete, sokszínúsége, a politikai és társadalmi problémák, valamint az alkotmányos tapasztalatok hiánya miatt kezdetben az is kérdéses volt, hogy India egyáltalán tud-e müködni egy modern alkotmány keretei között. Az indiai alkotmány terjedelmét tekintve is egyedülálló, amit többek között a hatalmas ország föderális berendezkedésének részletes szabályozása okoz. ${ }^{15}$

Az 1950-es alkotmány megalkotói úgy vélték, a parlamentnek van hatásköre az alkotmány megváltoztatására annak érdekében, hogy az ország társadalmi és gazdasági fejlődése során esetlegesen felmerülő kihívásokra reagálhasson. ${ }^{16} \mathrm{Az}$ indiai alkotmányt ennek megfelelően a mai napig százszor módosították, legutóbb 2015ben. ${ }^{17} \mathrm{Az}$ alkotmány 368 . cikke értelmében a parlament alkotmányozó hatalmát gyakorolva az alkotmány rendelkezéseinek bővítésével, módosításával vagy törlésével a cikkben meghatározott eljárásban változtathat az alkotmányon. Fő szabály szerint mind a két házban az összes képviselő többségének és egyben a jelenlévő és szavazó képviselők kétharmadának szavazata szükséges a törvényjavaslatként (bill) benyújtott alkotmánymódosítás elfogadásához, de tárgyköröktöl függően bizonyos esetekben - mint például maga az alkotmánymódosítás szabályai, az unió és az államok közötti hatáskörmegosztás, az elnök megválasztásának szabályai - legalább az állami parlamentek felének is ratifikálnia kell.

A jogszabályok alkotmányossága megkérdőjelezhető bármely bíróság előtt, de ha az ügyben érdemi jogi kérdést érintő alkotmányértelmezésre van szükség, akkor a felső bíróságoknak és végső soron a Bíróságnak kell döntenie. ${ }^{18} \mathrm{Az}$ alapvető jogok gyakorlása, védelme érdekében mindenkinek joga van megfelelő eljárások útján a Bírósághoz fordulni. ${ }^{19} \mathrm{Az}$ indiai alkotmány nem tartalmaz megváltoztathatatlan

14 WRIGHT: i. m., 760.

15 Singh, Mahendra Pal: India. In: Oliver, Dawn-Fusaro, Carlo (eds.): How Constitutions Change: A Comparative Study. Hart, Oxford, 2011, 169.

16 P. B. Gajendragadkar bírót idézi JacoBsoHn: i. m., 471.

17 https://www.india.gov.in/my-government/constitution-india/amendments (2018. 09. 25.).

18 India alkotmánya 132. § és 228. §. https://www.india.gov.in/sites/upload_files/npi/files/coi_part_full.pdf (2018. 09. 25.).

19 India alkotmánya 32. §. https://www.india.gov.in/sites/upload_files/npi/files/coi_part_full.pdf (2018. 09. 25.). 
rendelkezést, és kifejezett hatáskört sem ad az alkotmánymódosítások felülvizsgálatára.

Az alkotmánymódosítások felülvizsgálatához Indiában egyszerre legalább két történet kapcsolódik. Az egyik az évtizedes politikai adok-kapok a magántulajdon tekintetében, a másik a Bíróság elhúzódó harca hitelessége és függetlensége megalapozásáért a tekintélyét csökkenteni szándékozó kísérletekkel szemben. Ez a két narratíva Indira Gandhi működésével gyakorlatilag összefonódott. ${ }^{20}$ Indira Gandhi először 1966-1977 között, majd 1980-1984 között volt India miniszterelnöke, aki fel akart lépni a szegénység ellen, és szerette volna a hatalmát korlátozó, az alapvető struktúra védelmére épülö bírói gyakorlatot felszámolni. A Bíróság a másik szempontból is nehéz helyzetben volt, mert az angol gyarmati rendszert követő független alkotmányos demokráciában az alkotmány az előző rendszerben kialakult tulajdoni viszonyokat is védte a mindenkit megillető tulajdonhoz való jogon keresztül. Ez feszültséget okozott, hiszen az egyenlőség és a társadalmi igazságosság valamilyen szintú újraelosztást igényelt. Hasonló problémák gyakoriak a demokráciába való átmenet idején. ${ }^{21}$

\section{Az érdemi felülvizsgálat elutasítása}

A Bíróság 1951-ben találkozott először az alkotmányellenes alkotmánymódosítás problémájával. A Bíróság kezdetben nem vizsgálta felül az alkotmánymódosításokat tartalmi szempontból, mert az alkotmánymódosítást a parlament alkotmányozó hatalma gyakorlásának tartotta, amelynek csak eljárási korlátai vannak (kétharmados többség követelménye).

Ebben az időszakban a korábban hatalmas földterületeket birtoklók a kisajátítások miatt pereket indítottak az indiai állam ellen az új alkotmányban szereplő alapjogokra hivatkozva. A parlament 1951-ben fogadta el az első alkotmánymódosítást, ${ }^{22}$ válaszul egy tagállami bíróság kisajátítást megsemmisítő döntésére ${ }^{23}$ amely az alkotmány egyenlőségi rendelkezéseinek sérelmére hivatkozott. A módosítás céljaként kifejezetten az 1948 és 1951 között elfogadott földtörvények (zamindari abolition laws) alkotmányosságának biztosítását jelölték meg. ${ }^{24} \mathrm{Az}$ alkotmánymódosítással bevezetett 31A cikk lényegében azt mondta ki, hogy a kisajátítások nem semmisíthetők meg amiatt, hogy alapvető jogokat sértenek. A 31B cikk még tovább ment, és bevezette az alkotmány Kilencedik Jegyzékét (Ninth Schedule): ez felsorolja azon központi és állami törvényeket, amelyek az alapvető jogok sérelme miatt nem semmisíthetők meg. Ezzel az alkotmánymódosítással a parlament kizárta a földreform bírói felülvizsgálatát.

20 JacoBsohn: i. m., 472.

21 Lásd például a magyar Alkotmánybíróság igazságtételi döntését: 53/1993. (X. 13.) AB határozat, ABH 1993 , 323.

22 Buss, Andrea: Dual Legal Sytems and the Basic Structure Doctrine of Constituions. Canadian Jurnal of Law and Society, 2004/2, 35.

23 Kameshwar Singh v. State of Bihar, AIR 1951 Patna 91.

24 The Constitution (First Amendemnt) Act, 1951. https://www.india.gov.in/my-government/constitution-india/ amendments/constitution-india-first-amendment-act-1951 (2018. 09. 25.). 
A Shankari Prasad-ügyben ${ }^{25}$ korábbi földbirtokosok arra hivatkoztak, hogy az indiai alkotmány 13. cikk (1) bekezdése értelmében minden hatályban lévő jogszabálynak biztosítania kell az alapvető jogokat, egyébként semmisek. A 13. cikk (2) bekezdése tiltja, hogy az állam alapvető jogokat megszüntető vagy korlátozó jogot alkosson. A kérelmezők szerint az alkotmánymódosítás is jogszabály (law), még akkor is, ha kétharmados többséggel fogadják el.

Az indiai alkotmány 13. cikkét gyakran tekintik az alapvető jogok biztosítékának. Az alkotmánymódosítások felülvizsgálatával kapcsolatban azt kellett eldönteni, hogy az alkotmánymódosítás jogszabálynak (law) számít-e. ${ }^{26} \mathrm{Az}$ alkotmány 13 . cikk (3) bekezdése értelmében, hacsak a kontextus másként nem kívánja meg, a jogszabály (law) magában foglalja a rendeletet, a szabályt, az értesítést, a szokást is. ${ }^{27}$ Az alkotmány 12. cikke azt tartalmazza, hogy az alapvető jogokról szóló rendelkezések tekintetében, hacsak a kontextus másként nem kívánja meg, az „állam” kifejezés alatt India kormányát és parlamentjét, az államok kormányait és törvényhozását, és minden helyi vagy más, az indiai kormány ellenőrzése alatt álló hatóságot kell érteni.

A szóban forgó ügyben a Bíróság nem értett egyet a kérelmezővel, mert úgy vélte, hogy az alkotmánymódosítás elfogadásakor a parlament alkotmányozó hatalmát gyakorolja, és nem mint törvényhozó jár el, ezért a 13. cikk korlátozása nem vonatkozik rá. ${ }^{28}$ Kimondta, hogy „egyértelmü, tiszta határvonal van a rendes (ordinary) törvény és az alkotmányos tárgyak, jog között; az előbbi a törvényhozói, míg utóbbi az alkotmányozó hatalom gyakorlása". ${ }^{29}$

Az ügyben a kérelmező másik érve az volt, hogy a földreform alkotmányossági vizsgálatának kizárása korlátozza az államok felső bíróságainak (High Courts) hatáskörét, emiatt az erről szóló rendelkezést más alkotmánymódosítási eljárásban kellett volna elfogadni, azaz az államok felének is ratifikálnia kellett volna. A Bíróság elutasította ezt az érvet is, mert úgy ítélte meg: a bíróságok hatáskörét csak közvetetten érinti az alkotmánymódosítás. ${ }^{30}$

Néhány évvel később, 1954-ben több olyan bírói döntés született, melyek az alkotmány 31 . cikkét ${ }^{31}$ értelmezve arra jutottak, hogy a kisajátított földekért járó kártalanítás nem volt méltányos és megfelelő, ami a tulajdonhoz való jogot sértette. Az ítéletekre válaszul a parlament elfogadta a negyedik alkotmánymódosítást, amely szükítette a kártalanítások körét és tovább korlátozta a magántulajdonhoz való jogot. A folyamat az 1960-as években folytatódott. Két állam földreformjának bírói megsemmisítését követően a tizenhetedik alkotmánymódosítás hasonló módon további

25 Shankari Prasad Deo v. Union of India, 1951 (3) SCR 89.

26 KRISHNASWAmy, Sudhir: Democracy and Constitutionalism in India: A Study of the Basic Structure Doctrine. Oxford University Press, Oxford, 2011, 5.

27 "In this article, unless the context otherwise requires, - (a) »law includes any Ordinance, order, bye-law, rule, regulation, notification, custom or usage having in the territory of India the force of law."

28 Buss: i. m., 35.

29 Shankari Prasad Deo v. Union of India, 1951 (3) SCR 106.

30 Buss: i. m., 35.

31 Hatályon kívül helyezte a 44. alkotmánymódosítás 1978-ban. 
korlátozásokat vezetett be. A bírói felülvizsgálat kizárása érdekében módosította a 31. cikket és kibővítette a Kilencedik Jegyzékbe tartozó törvények körét. ${ }^{32}$

1965-ben a Bíróság második alkalommal döntött alkotmánymódosításról a Sajjan Singh-ügyben, ${ }^{33}$ és megerősítette a tizenhetedik alkotmánymódosítást a Shankari Prasad-döntéshez hasonló érveléssel. Elutasította a kérelmezők érveit, amelyek szerint az alkotmánymódosítás a felső bíróságok (High Courts) hatáskörét csökkenti (226. cikk), ezért más alkotmánymódosítási eljárásban kellett volna elfogadni (azaz az államok felének is jóvá kellett volna hagynia), továbbá alapvető jogokat is sért. Az 1951-es döntéssel ellentétben azonban a bírák nem voltak olyan egységes állásponton: $3: 2$ arányban hozták meg a döntést. A kisebbségben maradó bírák különvéleményükben felvetették, hogy vajon az alapvető jogok tényleg nem korlátozzák-e az alkotmánymódosító hatalmat (power of amendment), és az alapvető jogok valóban lehetnek-e olyan könnyen korlátozhatók, ahogy a parlament által addig bevezetett számos módosítás mutatta. ${ }^{34}$

\section{Az érdemi felülvizsgálat kezdetei}

Másfél évtizeddel később a Bíróság megváltoztatta az alkotmánymódosítások kizárólag eljárási szempontú felülvizsgálatát elfogadó álláspontját, és az alkotmánymódosításokat rendes törvényekként kezelve érdemi alkotmányos felülvizsgálatnak vetette alá azokat. Ez az álláspont az alkotmány 13. cikkén alapult, amely tiltja az alapvető jogokat megvonó vagy korlátozó jogalkotást. Ezenfelül az alapjogokat a parlament felett állónak mondták ki.

1967-ben a Golak Nath-esetben ${ }^{35}$ a Bíróság felülvizsgálta korábbi álláspontját. Az ügyben újra a már korábban vizsgált első, negyedik és tizenhetedik alkotmánymódosítás érvényességét vitatták azon az alapon, hogy az alkotmánymódosítás nem áll az eredeti alkotmánnyal azonos alapokon. Az érvelés szerint az alkotmányt az alkotmányozó hatalom fogadta el, az alkotmánymódosító hatalom (power of amanedment) viszont egyfajta törvényhozói hatalom, amelynek összhangban kell állnia az alkotmánnyal, különösen az alapvető jogokkal, és ezt a bíróság vizsgálhatja is. ${ }^{36}$

A testületet megosztotta az alkotmányjogi probléma. $6: 5$ arányban szavazták meg, ${ }^{37}$ hogy a Bíróság az alkotmánymódosítást rendes törvénynek, jogszabálynak (law) minősítse, amire így vonatkozik az alapjogokat védő 13. cikk, tehát még az alkotmány módosításával sem lehet az alapvető jogokat csorbítani. A testület értelmezése szerint a 13. cikk (3) bekezdése nem zárja ki a jogszabály (law) fogalmából

32 ManoJ, Mate: Two Paths to Judicial Power: The Basic Structure Doctrine and Public Interest Litigation in Comparative Perspective. San Diego International Law Journal, 2010/12, 180-181.

33 Sajjan Singh v. State of Rajasthan, 1965 (1) SCR 933.

34 SINGH: i. m., 176.

35 Golak Nath v. State of Punjab, AIR 1967 SC 1643.

36 SINGH: i. m., 176-177, összefoglalja a Golak Nath-ügy kérelmezőjének érveit.

37 Manos (2010): i. m., 181. 
az alkotmánymódosítást. ${ }^{38} \mathrm{Az}$ alkotmánymódosítás szabályait meghatározó 368 . cikket a Bíróság úgy értelmezte, hogy a kétharmados többség követelménye csak a törvényjavaslat elfogadásának eljárását határozza meg és nem hatásköri szabály, nem az alkotmány módosítására hatalmaz fel, tehát az alkotmánymódosítás különleges többséggel elfogadott rendes törvény, amely bírói felülvizsgálat tárgya lehet. ${ }^{39}$ Ezzel a Bíróság az alkotmánymódosítás kifejezett korlátaiként azonosította az alapvető jogokat, szakítva korábbi, az alkotmánymódosítások korlátlanságát támogató álláspontjával. A szakítás az emberi jogok felfogásában bekövetkező változás következménye. A Bíróság ugyanis kimondta: az alapjogok az alkotmány alapján transzcendentális helyzetüek, és így a parlament felett állók, ${ }^{40}$ azaz lényegében megváltoztathatatlanok. Ennek ellenére a Bíróság végül nem semmisítette meg az ügy alapját képező első, negyedik és tizenhetedik alkotmánymódosításokat - holott azokat alapjogsértőnek ítélte meg -, mert döntését a jogbiztonság követelményére tekintettel csak a jövőbeni alkotmánymódosításokra kívánta alkalmazni (prospective overruling), ${ }^{41}$ és a parlamentnek szóló figyelmeztetésnek is szánta. A kisebbségben maradt bírák nem értettek egyet azzal, hogy az alkotmánymódosításról szóló 368 . cikk csupán egy különleges jogalkotási eljárás szabályozása lenne; álláspontjuk szerint alkotmánymódosító hatalmat hoz létre, ami alkotmányos normák elfogadására hatalmaz fel. ${ }^{42}$

\section{Az alapvető struktúra védelme}

A parlament olyannyira nem értett egyet a Bíróság Golak Nath-ügyben kifejtett értelmezésével, hogy alkotmánymódosítással írták felül a döntés érveit, amire válaszul a Bíróság, újra irányt váltva, visszalépett korábbi pozíciójától és elismerte: a parlament az alkotmány bármely rendelkezését módosíthatja. Viszont ezzel párhuzamosan implicit korlátot állított fel az alkotmánymódosításokra nézve. Megállapította, hogy egyetlen alkotmánymódosítás sem lehet olyan, ami az indiai alkotmány alapvető struktúráját sérti.

A parlament és a Bíróság viszonyában, az alkotmánymódosítások felülvizsgálatának alakulásában fontos szerepet játszott két olyan eset, amely közvetlenül nem alkotmánymódosítások felülvizsgálatára irányult. Az 1970-es R. C. Cooper-ügyben ${ }^{43}$ a Bíróság megsemmisítette a nagyobb bankokat államosító törvényt, mert nem kaptak megfelelő kártalanítást. Az 1971-es Madhav Rao Scindia-ügyben ${ }^{44}$ a címek és kiváltságok eltörlését célzó törekvéseknek szabott gátat a Bíróság. ${ }^{45}$

38 SINGH: i. m., 177.

39 Manos (2010): i. m., 181-182, a Golak Nath-döntés többségi érvelését idézi.

40 Golak Nath v. State of Punjab 1656. Idézi JacoBsohn: i. m., 473.

41 Buss: i. m., 36 .

42 O'ConnelL, Rory: Guardians of the Constitution: Unconstitutional Constitutional Norms. Journal of Civil Liberties, 1999/4, 20.

43 R. C. Cooper v. Union of India AIR 1970 SC 564.

44 Madhav Rao Scindia v. Union of India AIR 1971 SC 530.

45 MANOJ (2010): i. m., 182. 
1971-ben, előrehozott választásokon Indira Gandhi vezetésével a Kongresszus Párt az alkotmány módosításához is elegendő kétharmados többséget szerzett, és ahogy a választási kampányban arra ígéretet tettek, alapvető, a bíróságokat is érintő változtatásokat hajtottak végre. A parlament a Bíróság hatáskörét csökkentő, döntéseit felülíró alkotmánymódosításokat fogadott el. ${ }^{46}$

A huszonnegyedik alkotmánymódosítást a Golak Nath-döntésre válaszul fogadta el az indiai parlament. ${ }^{47}$ A módosítás indoklása szerint a Bíróság ítélete értelmében a parlament nem fogadhatna el alapvető jogokat elvevő vagy korlátozó alkotmánymódosításokat még akkor sem, ha az szükséges az ország kormányzására, illetve a törvényhozásra vonatkozó célok és elvek (Directive Principles of State Policy) megvalósítása érdekében. (Ezen célok előmozdítását az alkotmány 37 . cikke kifejezetten az állam kötelességévé teszi.) Éppen ezért az alkotmány módosítói szerint szükséges kifejezetté tenni, hogy a parlamentnek alkotmányozó hatalomként joga van az alkotmány bármely részét módosítani. A Golak Nath-döntésre válaszul a huszonnegyedik alkotmánymódosítás megváltoztatta a 368. cikk címét (Power of Parliament to amend the Constitution and procedure therefor), hogy a bírák ne tarthassák fenn azt az értelmezésüket, hogy az abban foglaltak csupán eljárási szabályok, hanem kénytelenek legyenek hatásköri szabályként tekinteni rájuk. Az alkotmánymódosítás kibővítette a 368. cikket azzal a rendelkezéssel, hogy a parlament alkotmányozó hatalomként az alkotmány bármely rendelkezését módosíthatja hozzáadással, változtatással, törléssel a 368. cikk szerinti eljárásnak megfelelően. Valamint az alkotmánymódosítás bevezette, hogy az alkotmány 13. cikke nem alkalmazható az alkotmánymódosításokra.

A huszonötödik alkotmánymódosítás lényegében a bankok államosításával kapcsolatban hozott bírói döntés felülalkotmányozása. A módosítás kizárta a bírói felülvizsgálatot az olyan jogszabályokra nézve, amelyek az ország kormányzására, illetve a törvényhozásra vonatkozó célok és elvek (Directive Principles of State Policy) megvalósítását szolgálják. Ezenfelül további korlátozást vezetett be a tulajdonjogot védő 31. cikkben. A földreform végrehajtásának biztosítására a „kártalanítás” helyett az „összeg” szót emelte be az alkotmányba, a kedvezőtlen bírói döntések, mint például az R. C. Cooper-ügyhöz hasonló ítéletek megelőzésére. Így az elvett földek után járó összeg miatt nem lehetett bírósághoz fordulni azon az alapon, hogy nem megfelelő összegü a kártalanítás. A huszonhatodik alkotmánymódosítás a címek és az azokhoz kapcsolódó juttatások megszüntetését valósította meg, felülírva a Madhav Rao Scindia-ügyben hozott bírói döntést. A módosításhoz füzött indokolás szerint azért volt szükség az alkotmánymódosításra, mert a semmilyen megbízatáshoz vagy társadalmi célhoz sem kapcsolódó juttatásokat és különleges jogokat biztosító uralkodás fogalma összeegyeztethetetlen egy egalitárius társadalmi renddel. ${ }^{48}$ A huszonkilencedik alkotmánymódosítás a Kilencedik Jegyzéket kibővítette

46 SATHE, S. P.: India: From Positivism to Structuralism. In: Goldsworthy, Jeffrey (ed.): Interpreting Constitutions: A Comparative Study. Oxford University Press, Oxford, 2007, 243.

47 The Constitution (Twenty-fourth Amendment) Act, 1971. https://www.india.gov.in/my-government/ constitution-india/amendments/constitution-india-twenty-fourth-amendment-act-1971 (2018. 09. 25.).

48 The Constitution (Twenty-sixth Amendment) Act, 1971. https://www.india.gov.in/my-government/constitutionindia/amendments/constitution-india-twenty-sixth-amendment-act-1971 (2018. 09. 25.). 
Kerala állam két újabb földreformtörvényével, kivonva azokat a bírói felülvizsgálat alól.

Az alapvető struktúra doktrínát megalapozó Kesavananda Bharati-ügy ${ }^{49}$ a huszonnegyedik, a huszonötödik és a huszonkilencedik alkotmánymódosításokkal foglalkozott. A Bíróság $7: 6$ arányú döntéssel szakított korábbi gyakorlatával, és felülbírálta a Golak Nath-ügyben lefektetett érvelését. A testület megosztottságát a szoros szavazati arányon túl az ítélet meglehetősen nagy terjedelme is jelezte.

A Bíróság a korábbi döntését felülalkotmányozó huszonnegyedik alkotmánymódosítást elfogadva kimondta, hogy az alkotmánymódosítás nem rendes törvény (law), ezért nem vonatkozik rá az alapvető jogokat védő 13 . cikk. ${ }^{50}$ Elismerte a parlament jogát az alkotmány bármely, akár alapvető jogokat érintő rendelkezéseinek megváltoztatására. Ezzel kapcsolatban úgy fogalmaz a döntés, hogy az alapvető jogokat az alkotmány biztosítja (given by), ezért azokat alkotmánymódosítással korlátozni és elvenni is lehet. A természetes jogok időszaka ezzel rövid véget ért, hasonlóan azonban az amerikai legfelső bíróság Marbury versus Madison döntéséhez, a Bíróság a kormánnyal szembeni direkt konfrontációt elkerülve megerősítette saját pozícióját, ${ }^{51}$ mivel implicit korlátot állított az alkotmánymódosítás elé. Kimondta, hogy a 368. cikk az alkotmány alapvető struktúrájának és keretrendszerének megváltoztatására nem hatalmazza fel a parlamentet. ${ }^{52} \mathrm{~A}$ Bíróságot, úgy tünik, meggyőzte a föügyész, aki szerint, ha a parlament alkotmánymódosítással teljesen megváltoztathatja az alkotmányt, akkor lerombolhatja a demokráciát, autokráciát kiépítve, vagy a szekuláris államot leválthatja egy teokratikusra. ${ }^{53} \mathrm{~A}$ döntésben a Bíróság úgy fogalmazott, hogy ha a 368. cikk szerinti hatalom korlátlan lenne, akkor az alkotmány saját maga lerombolásának lenne a forrása. ${ }^{54} \mathrm{~A}$ Bíróság a huszonnegyedik és huszonkilencedik alkotmánymódosításokat elfogadta, míg a huszonötödik módosítást az alapvető struktúrát sértő módosításnak ítélte. ${ }^{55}$

Arról, hogy pontosan milyen elemei lehetnek az alapvető struktúrának, a bírák véleményeiböl alkothatunk képet. ${ }^{56} \mathrm{~A}$ bírák között volt, aki a „módosítás” szó értelmezésével jutott arra, hogy a módosítás nem lehet olyan, ami az alkotmányt lecseréli egy új alkotmányra. Mások az alkotmány teljességéből, egységességéből kiindulva gondolták úgy, hogy az alkotmány nemcsak kifejezett, hanem implicit korlátokat is tartalmaz az alkotmánymódosításokra nézve, és így az alkotmány módosítására vonatkozó felhatalmazás nem foglalja magában az alkotmány alapvető struktúrájának megváltoztatását. ${ }^{57} \mathrm{C}$. J. Sikri bíró szerint az egyének méltóságára és szabadságára épülő alapvető struktúra öt részből áll: (i) az alkotmány felsősége (supremacy), (ii)

49 Kesavananda Bharati v. State of Kerala AIR 1973 SC 1461.

50 BARAK: i. m., 326.

51 JACOBSOHN: i. m., 474.

52 Kesavananda Bharati v. State of Kerala AIR 1973 SC 1466.

53 SATHE: i. m., 244.

54 Kesavananda Bharati v. State of Kerala, 1490.

55 Manos (2010): i. m., 184.

56 Az összes vélemény részletes ismertetését lásd JAIN, Sanjay S.-NARAYAN, Sathya: Basic Structure Constitutionalism: Revisiting Kesavananda Bharati. Eastern Book Company, Lucknow, 2011.

57 BARAK: i. m., 326. 
a demokratikus köztársasági kormány, (iii) szekularizmus, (iv) a hatalmi ágak elválasztása, (v) föderalizmus. ${ }^{58}$

A kisebbségben maradó hat bíró szerint azonban az alkotmány minden rendelkezése azonos státuszú, egyik sem élvezhet elsőbbséget a másikkal szemben. Az alkotmánymódosító hatalmat (amending power) akár alapvető rendelkezéseinek megváltoztatására is felhatalmazza az alkotmány. ${ }^{59} \mathrm{~A}$ kisebbségben maradók véleményét személetesen fejezi ki $Y$. V. Chandrachud bíró álláspontja, aki szerint, ha a nép a parlament útján cselekedve szeretné a király koronáját egy olyan fejre helyezni, amelyet szeret, vagy ha úgy tetszik, nem szeret, hagyjuk meg neki ezt a szabadságot. ${ }^{60}$

A döntés érdekessége, hogy a Bíróság - lényegében reagálva a Kongresszus Párt választási kampányára, amelyben deklarált célként hirdette meg a Golak Nathdöntés felülalkotmányozását - megjegyezte: a parlamenti képviselők kétharmada nem képviseli az ország népének többségét sem, mivel a választási rendszer olyan, hogy a választók kisebbsége meg tudja választani a parlament kétharmadának tagjait. ${ }^{61}$

\section{Az alapvető struktúra doktrína megerősítése}

A Bíróság Kesavananda-döntése sok kritikát kapott, de a későbbi, alkotmánymódosításokat is eszközként használó autoriter törekvésekkel szemben ellensúlyt képező bírói gyakorlat végül megalapozta az alapvető struktúra doktrína elfogadottságát. Két évvel később, 1975-ben a Bíróság újra alkotmánymódosításokról döntött az Indira Gandhi-ügy ${ }^{62}$ kapcsán. Az eset előzménye Allahabad állam felső bíróságának ítélete volt, amely korrupció miatt érvénytelenítette Indira Gandhi parlamenti megválasztását és hat évre eltiltotta bármilyen választáson indulástól. Ezt követően Gandhi kezdeményezésére az elnök szükségállapotot vezetett be belső zavargásokra hivatkozva, holott már rendkívüli állapot volt hatályban külső támadás és háború miatt. A szükségállapot ideje alatt ellenzéki vezetőket, köztük több parlamenti képviselőt letartóztattak, és az alkotmányt is több alkalommal módosították rövid idő alatt. ${ }^{63} \mathrm{~A}$ harmincnyolcadik alkotmánymódosítás megtiltotta a szükségállapot bevezetésének bírói felülvizsgálatát, míg a Gandhi-ügy alapját képező harminckilencedik alkotmánymódosítás visszaható hatállyal változtatott a választás szabályain, és a miniszterelnök megválasztásával kapcsolatos ügyeket kivonta a bírói felülvizsgálat alól, amit a folyamatban lévő ügyekre - tehát Indira Gandhi ügyére - is alkalmazni rendelt.

A Bíróság alkotmányellenesnek találta az alkotmánymódosítás bírói felülvizsgálatot csorbító részét, mert az ellentétes az alapvető struktúrával, de elismerte a visz-

\footnotetext{
58 Kesavananda Bharati (1973) 4 S.C.C. 225, 316-317. Idézi Manos (2010): i. m., 184.

59 O'Connell: i. m., 21.

60 Idézi JaCoBsohn: i. m., 475.

61 Kesavananda Bharati (1973) 4 S.C.C. 481. Idézi MAnos (2010): i. m., 184.

62 Indra Nehru Gandhi v. Raj Narain AIR 1975 SC 2299.

63 SINGH: i. m., 178.
} 
szamenőleges jogalkotást és ezzel Indira Gandhi megválasztását ${ }^{64}$ A $4: 1$ arányban hozott, a Kesavananda-ügyben kifejtett alapvető struktúra doktrínát megerősítő döntésben az alkotmánymódosítást többféle értelmezés alapján itélték semmisnek a bírák. Khanna bíró szerint azért sértette az alkotmánymódosítás az indiai alkotmány alapvető struktúráját, mert ellentmond a demokrácia és jogállamiság értékeinek, mivel a demokrácia szabad és tisztességes választásokat kíván. Ray és Matthew bírák szerint az alkotmányozó hatalom nem használható fel a bírói hatalom gyakorlására, míg Chandrachud bíró az alkotmánymódosítást az egyenlőség nyílt tagadásának minősítette, ami önkényes és tervezetten rombolja a jogállamiságot. ${ }^{65}$

Indira Gandhi szeretett volna megszabadulni az alapvető struktúra védelmére épülő bírói gyakorlattól, valamint szocialista mintára akarta felszámolni a szegénységet. Ezen célok elérése érdekében a parlament 1976-ban átfogó, mintegy hatvan fontos változást hozó alkotmánymódosítást fogadott el. ${ }^{66} \mathrm{~A}$ negyvenkettedik alkotmánymódosítás például bevezette, hogy az alkotmánymódosításnak nincsenek korlátai, és ezt egyetlen bíróság sem vonhatja kétségbe semmilyen alapon. A preambulumban a „szuverén demokratikus köztársaság” megjelölést a „szocialista” és „szekuláris” jelzőkkel egészítette ki; az alapvető jogokkal szemben elsőbbséget adott az ország kormányzására, illetve a törvényhozásra vonatkozó célok és elvek (Directive Principles of State Policy) megvalósításának; megtiltotta a Bíróságnak, hogy vizsgálja az állami törvények összeegyeztethetőségét az alapjogokkal; megtiltotta a felső bíróságoknak, hogy a központi jogszabályok alkotmányossági vizsgálatát elvégezzék; új közigazgatási bíróságok létrehozását írta elö.

A negyvenkettedik alkotmánymódosítás hatálybalépése után nem sokkal megszűnt a szükségállapot és választások zajlottak, amelyek Indira Gandhi és pártja vereségét hozták. Az új kormány az 1978-as negyvenharmadik és az 1979-es negyvennegyedik alkotmánymódosításokkal lényegében visszaállította az alkotmány korábbi, harmincnyolcadik, harminckilencedik és negyvenkettedik alkotmánymódosítása előtti állapotát. ${ }^{67} \mathrm{~A}$ Janata Párt többségú parlament azonban az alkotmányos helyreállítást nem tudta teljes mértékben véghez vinni, mert a parlament felsőházában még mindig sok támogatója volt Indira Gandhinak. ${ }^{68}$

A negyvenkettedik alkotmánymódosításnak azonban maradt még két fontos rendelkezése, amit a Bíróság a Minerva Mills-ügyben ${ }^{69}$ semmisített meg. Az ügy alapjául a textilüzemeket államosító törvényt a Kilencedik Jegyzékbe utaló - azaz a bírói felülvizsgálat alól kivonó - harminckilencedik és negyvenkettedik alkotmánymódosítás szolgált. A törvény szerint az Állami Textil Vállalat átvette a Minerva Mills textilipari üzem irányítását arra hivatkozva, hogy azt tulajdonosai a közérdeket károsító módon kezelték. A kérelmezők a törvény Kilencedik Jegyzékbe kerülését, az alkotmány tulajdonjogi rendelkezéseit tartalmazó 31. cikk és a negyvenkettedik alkotmánymódosítással az alkotmányba kerülő, az alkotmánymódosítások korlátlan-

64 SINGH: i. m., 179.

65 Indra Nehru Gandhi (1975) Supp. S.C.C. 1, 90-92, 257-258. Idézi Manou (2010): i. m., 186.

66 SINGH: i. m., 179.

67 SINGH: i. m., 180.

68 O'Connell: i. m., 23.

69 Minerva Mills Ltd. v. Union of India AIR 1980 SC 1789. 
ságát és azok bírói felülvizsgálat alóli mentességét biztosító rendelkezések alkotmányosságát kérdőjelezték meg.

A Bíróság az alapvető struktúrával nem tartotta összeegyeztethetőnek a 368. cikk (4)-(5) bekezdéseit, amelyek nem engedték, hogy az alkotmánymódosításokat bármely bíróság bármilyen alapon megkérdőjelezze, illetve deklarálták az alkotmányozó hatalmat gyakorló parlament hatáskörének korlátlanságát. A textilipari vállalat államosításával kapcsolatos ügyben a Bíróság megállapította, hogy a korlátozott alkotmánymódosító hatalom (amending power) az alkotmány alapvető vonása, ezért ennek a hatalomnak a korlátait nem lehet lerombolni. ${ }^{70} \mathrm{C}$. J. Chandrauchud bíró szavaival: „mivel az alkotmány korlátozott módositó hatalmat biztositott a parlamentnek, a parlament ennek a korlátozott hatalomnak a gyakorlása során nem bővitheti abszolúttá hatáskörét. [...] Az alkotmány identitásának lerombolására adott felhatalmazás, azzal a rendelkezéssel együtt, hogy egyetlen bíróság sem vonhatja kétségbe ilyen rombolás érvényességét, számunkra egyértelmüen a módositó hatalom áthágása." ${ }^{71} \mathrm{Az}$ alapvető jogokat felülíró, az ország kormányzására, illetve a törvényhozásra vonatkozó célokat és elveket (Directive Principles of State Policy) tartalmazó 31C cikket szintén érvénytelenítette a bíróság, mivel lerombolja az alapvető jogok és az elvek közötti egyensúlyt, ami alapvető jellemzője (essential feature) az indiai alkotmánynak. ${ }^{72}$

Indira Gandhi 1980-ban újra hatalomra került, de már nem volt elegendő támogatottsága további, a Bíróság gyakorlatát felülbíráló alkotmánymódosításhoz vagy más, a Bíróság működését befolyásoló fellépéshez.

\section{Az alapvető struktúra védelmének kiterjesztése és pontosítása}

Az alapvető struktúra doktrína megerősítését követő 1990-es és 2000-es években született döntések továbbfejlesztették az addigi gyakorlatot, és új szempontokat hoztak annak eldöntéséhez, hogy az alkotmány mely részei alapvető jelentőségüek. Továbbá kiterjesztették a doktrína alkalmazási területét, ami így már nem csak az alkotmánymódosítások alkotmányossági vizsgálatának mércéjeként azonosítható.

A Bommai-ügyben ${ }^{73}$ a Bíróság az elnök szükségállapot idején hozott döntéseit vizsgálta. A jobboldali hindu koalíció kampányt indított, ami a Barbi Masjid nevű mecset lerombolásához vezetett. A mecsetet lerombolók szerint a mecset egy ősi hindu templom romjain épült. Az események Uttar Pradesh állam Bharatiya Janata Párthoz (BJP) kötődő kormányának jóváhagyásával történtek, ami India-szerte erőszakos fellépéseket eredményezett. Az erőszakhullám megfékezésére India elnöke az alkotmány 356. cikke alapján intézkedett. Feloszlatta a BJP-hez kötődő kormányokat és hat állam törvényhozó testületeit.

\footnotetext{
Minerva Mills Ltd. v. Union of India AIR 1980 SC 1789.

Buss: i. m., 38.

Buss: i. m., 38.

73 S. R. Bommai v. Union of India (1994) 3 S.C.C. 1 (India).
} 
A Bíróság az elnök rendelkezéseit alkotmányosnak ítélte, mert ezek a lépések szükségesek voltak az alkotmány alapvető struktúrájának védelme érdekében, mivel a Bíróság szerint a feloszlatott kormányok nem az alapvető struktúra részét képező szekularizmus keretei között müködtek. A Bíróság a demokrácia és a föderalizmus védelmével indokolta az elnök szükségállapot alatt hozott intézkedéseinek felülvizsgálatát. Ezen értékeket is az alkotmány alapvető vonásai közé sorolta, kiterjesztve az alapvető struktúra doktrína alkalmazási területét. ${ }^{74}$

A Nagaraj-ügyben a Bíróság továbbfejlesztette az alapvető struktúra elemeinek meghatározását. Rögzítette, hogy csak úgy lehet különbséget tenni az alkotmány alapvető és nem alapvető jellemzői között, ha az egyes rendelkezéseket elvekhez kötik. A föderalizmus, a szekularizmus vagy a szocializmus például olyan rendszerszintü, strukturális elvek, amelyek az alkotmány egyes rendelkezései felett állva több rendelkezés alapjául szolgálnak. Ezek az elvek teszik az alkotmányt egésszé és biztosítják annak koherenciáját. ${ }^{75}$

\section{Következtetések}

A Bíróság két különböző érvelést fogadott el az alkotmánymódosítások felülvizsgálatára. Az első, és később felülbírált Golak Nath-döntésben alkalmazott érvelés szerint az alkotmánymódosítások rendes törvények, így az alkotmány 13. cikke alapján bírói felülvizsgálat tárgyai lehetnek. A 13. cikk pedig kifejezett alkotmányos korlátot jelentve tiltja az alapvető jogokat korlátozó módosítást. A másik érvelést a Kesavananda-ügyben fejtette ki a Bíróság. Eszerint az alkotmánymódosításoknak az alkotmány alapvető struktúráját tiszteletben kell tartaniuk, és ennek az implicit korlátnak az érvényesülését a Bíróság felülvizsgálja. ${ }^{76}$

$A z$ alapvető struktúra doktrínát eredetileg az alkotmány egyes rendelkezéseire vonatkoztatták, majd később úgy tünt, az alkotmányi szabályok közötti kapcsolatra vonatkozott, míg újabban inkább elvekre alkalmazzák. ${ }^{77}$ A Golak Nath-döntésben a Bíróság még az alapvető struktúra kifejezést sem használta (jóllehet az ügyben fellépő jogászok igen), és a fő kiindulópont az alapvető jogok sérthetetlensége volt. ${ }^{78}$ Az ügyben a Bíróság az alkotmány szövege alapján az alkotmánymódosításokat értelmezhette úgy, hogy beleférnek a jogszabály (law) 13. cikk szerinti meghatározásába, mivel az nem taxatív felsorolást ad, és az alkotmánymódosítást meghatározó 368. cikk is törvényjavaslat (bill) formájában írja elő az alkotmánymódosítás benyújtását. $\mathrm{Az}$ az értelmezés azonban, amely szerint az alkotmánymódosításra a 368. cikkben adott felhatalmazás csak a módosítások elfogadásának eljárási kereteit meghatározó rendelkezés, talán túlmegy a szokásosan alkalmazott értelmezési

74 ManoJ, Mate: State Constitutions and the Basic Structure Doctrine. Columbia Human Rights Law Review, 2014/2, 478-479.

75 M. Nagaraj v. Union of India (2006) A.I.R. 2007 S.C. 71 (India). Idézi Manou (2014): i. m., 480.

76 KRISHNASWAMY: i. m., 2.

77 Buss: i. m., 38.

78 Buss: i. m., 39. 
módszerek által behatárolt körön. HM Seervai szerint az ítélet egyértelmüen hibás volt, és az első adandó alkalommal felül kellett volna vizsgálni. ${ }^{79}$

A Kesavananda-ügyben megváltozott a Bíróság hozzáállása. Feladta a Golak Nath-döntés szinte módosításellenes merevségét, és elismerte a parlament jogát arra, hogy az alkotmány bármely rendelkezésén változtasson. Ezzel párhuzamosan implicit korlátot állított az alkotmánymódosításokkal szemben, mivel kimondta, hogy azok nem sérthetik az indiai alkotmány alapvető struktúráját. Az alapvető struktúra elemeit sem a Kesavananda-ügyben, sem később nem törekedett konkrétan és egységesen meghatározni. Az Indira Gandhi-ügyben Chandrachud bíró így fogalmazott: a testület tagjai között volt eszmecsere arról, hogy az alkotmány mely vonásai képezik az alapvető struktúra részét a Kesavananda-döntés alapján, de ő úgy gondolja, a döntés ratiója inkább az, hogy az alkotmánymódosító hatalom nem gyakorolható az alapvető struktúra megsértésével - jelentsen ez bármit. Az alapvető struktúra tartalmát szerinte csak esetről esetre lehet meghatározni. ${ }^{80}$

Az esetröl esetre mérlegelés amellett, hogy rugalmasságot biztosít, más elönyökkel is jár. Egyrészt az alapstruktúra-szempontú felülvizsgálat nem az alkotmány egy konkrét szakaszára épít, amit a parlament egy alkotmánymódosítással meg tudna változtatni. Másrészt az implicit korlát betartásának értékelése olyan felülvizsgálatot igényel, ami különbséget tesz a rendes állami cselekvés (state action) és az alkotmánymódosítás alkotmányos korlátai között. Harmadrészt a részletesen meghatározott alkotmányban szerepelő alapjogi rendelkezések középpontba állítása helyett általános alkotmányos elveket ajánl az alkotmánymódosítás korlátaiként. Negyedrészt a Bíróság azzal, hogy megkülönbözteti az alapvető jogi felülvizsgálatot az alapstruktúra-szempontú felülvizsgálattól, lehetőséget ad az alapvető alkotmányos értékek demokratikus koncepciójának kifejezésére az alapvető szerkezeti felülvizsgálat által védett alkotmányos elvektől való eltérés nélkül. ${ }^{81}$

Granville Austin a Golak Nath-döntést a parlament és a Bíróság elsőbbségért vívott háborújának kezdeteként aposztrofálta. ${ }^{82} \mathrm{Ez}$ azonban felfogható úgy is, hogy itt kezdődött meg a törékeny új demokrácia erodálódása. Indira Gandhi első hivatali idejében 11 év alatt huszonöt alkotmánymódosítást fogadott el a parlament. Az alkotmánymódosítások magas száma önmagában természetesen nem jelzi biztosan a problémákat, de az alkotmányellenes alkotmánymódosítás kérdése gyakran akkor merül fel, ha az alkotmányos demokrácia kereteit az alkotmánymódosító hatalom kezdi szétfeszíteni. A Kesavananda-döntés után széles körben vélekedtek úgy, hogy a Bíróság tévesen érzékelte, hogy a parlament visszaélt a hatalmával, a szükségállapot idején elfogadott alkotmánymódosításokkal kapcsolatban azonban helyesen mérte fel a helyzetet.

Az Indira Gandhi-ügyben hozott döntés legitimációt adott az alapvető struktúra doktrínának. ${ }^{83}$ Sathe szerint a fejlődő társadalmakban, ahol az egyéni szabadság

\footnotetext{
79 Seerval, H. M.: Constitutional Law. NM Tripathi, Bombay, 1967, 1117. Idézi Sathe: i. m., 243.

80 Buss: i. m., 40.

81 KRISHNASWAMY: i. m., 4.

82 Austin, Granville: Working a Democratic Constitution. The Indian Experience. Oxford University Press, New York, 1999, 198. Idézi HaLmal: i. m., 86.

83 SATHE: i. m., 247.
} 
és a jogállamiság még nem mélyen gyökerező társadalmi értékek, és a demokrácia hajlamos keményen többségi elven müködni, a bírói felülvizsgálat alapvető biztosíték ${ }^{84} \mathrm{~A}$ Bíróság bátran vállalta az alapvető struktúra védelmét a nagy jelentőségü Minerva Mills-ügyben is, Gandhi ismételt hatalomra kerülése után négy hónappal. ${ }^{85}$ Indira Gandhi második ciklusában, a választók támogatásának hiányában már nem próbálkozott a Bíróságot ellehetetlenítő és korlátozó eszközök alkalmazásával. Arató András szerint Carl Schmittnek igaza volt abban, hogy a kormányzat és a bíróságok közötti versengésben az előbbi az erősebb, viszont hozzáteszi, hogy ez csak abban az esetben állja meg a helyét, ha a bíróságoknak nincs társadalmi támogatottsága. Úgy látja, hogy a szükségállapot idején Gandhinak sikerülhetett volna ellehetetleníteni a Bíróságot, de kénytelen volt meghátrálni, mert 1977-ben vereséget szenvedett a választásokon. ${ }^{86}$

Egyértelműen látszik, hogy a bíróságok önmagukban nem tudják megakadályozni az autokratikus vonásokat mutató intézkedéseket, illetve ilyen rendszer kiépülését. Indiában az 1975-77 közötti szükségállapot utáni konszolidációt az alkotmányos demokráciát tisztelő és többséget szerző Janata Párt nélkül nem lehetett volna megvalósítani. Az, hogy a bíróságok önmagukban nem képesek gátat szabni a demokráciát veszélyeztető törekvéseknek, éppen azt mutatja meg, hogy az alkotmány korlátozott hatalmakat hozott létre, amelyeknek együttesen kell úgy müködniük, hogy az alkotmányos demokrácia kereteit és az emberi jogokat tiszteletben tartsák.

Az indiai legfelső bíróság megközelítése számos országban talált követőkre Ázsiától Dél-Amerikáig. A megváltoztathatatlan rendelkezéseket nem tartalmazó alkotmányok esetén a bíróságok az alapstruktúra védelméhez hasonló implicit korlátok felállításával határoztak meg egy elvekből, alkotmányos értékekböl, szabályokból álló olyan magot, amelyet az alkotmánymódosítások sem ronthatnak le. ${ }^{87}$

\section{Abstract}

One of the rare but more prominent cases of judicial protection of the existing constitution is the revision of constitutional amendments. From among courts that review amendments, this study presents India's Supreme Court's practice, which is regarded as a model. India's constitution does not contain any unamendable provisions or explicit authorization for judicial control over constitutional amendments, yet the court reviews constitutional amendments on grounds of protecting the constitution's basic structure. India's Supreme Court's practice is a typical example of a court imposing an implicit limitation upon constitutional amendments. Therefore, before analyzing the basic structure doctrine, the study briefly examines the nature of the implicit limitations of constitutional amendments and some issues that may arise in their justification.

84 SATHE: i. m., 247

85 O'Connell: i. m., 23-24.

86 ARATo, Andrew: Post Sovereign Constitution Making: Learning and Legitimacy. Oxford University Press, Oxford, 2016, 221.

87 Lásd erről bővebben RoznAl (2017): i. m., 47-71. 